\title{
Downward hydrocarbon migration predicted from numerical modeling of fluid overpressure in the Paleozoic Anticosti Basin, eastern Canada
}

\author{
G. $\mathrm{CHI}^{1}$, D. LAVOIE ${ }^{2}, \mathrm{R} \cdot \mathrm{BERTRAND}{ }^{3}$ AND M.-K. LEE ${ }^{4}$ \\ ${ }^{1}$ Department of Geology, University of Regina, Regina, SK, Canada; ${ }^{2}$ Geological Survey of Canada - Quebec Division, \\ Quebec, QC, Canada; ${ }^{3}$ INRS - ETE, Quebec, QC, Canada; ${ }^{4}$ Department of Geology, Auburn University, Auburn, AL, USA
}

\begin{abstract}
The Anticosti Basin is a large Paleozoic basin in eastern Canada where potential source and reservoir rocks have been identified but no economic hydrocarbon reservoirs have been found. Potential source rocks of the Upper Ordovician Macasty Formation overlie carbonates of the Middle Ordovician Mingan Formation, which are underlain by dolostones of the Lower Ordovician Romaine Formation. These carbonates have been subjected to dissolution and dolomitization and are potential hydrocarbon reservoirs. Numerical simulations of fluid-overpressure development related to sediment compaction and hydrocarbon generation were carried out to investigate whether hydrocarbons generated in the Macasty Formation could migrate downward into the underlying Mingan and Romaine formations. The modeling results indicate that, in the central part of the basin, maximum fluid overpressures developed above the Macasty Formation due to rapid sedimentation. This overpressured core dissipated gradually with time, but the overpressure pattern (i.e. maximum overpressure above source rock) was maintained during the generation of oil and gas. The downward impelling force associated with fluid-overpressure gradients in the central part of the basin was stronger than the buoyancy force for oil, whereas the buoyancy force for gas and for oil generated in the later stage of the basin is stronger than the overpressure-related force. Based on these results, it is proposed that oil generated from the Macasty Formation in the central part of the basin first moved downward into the Mingan and Romaine formations, and then migrated laterally up-dip toward the basin margin, whereas gas throughout the basin and oil generated in the northern part of the basin generally moved upward. Consequently, gas reservoirs are predicted to occur in the upper part of the basin, whereas oil reservoirs are more likely to be found in the strata below the source rocks.
\end{abstract}

Key words: Anticosti basin, fluid overpressure, hydrocarbon generation, basinal fluid flow, hydrocarbon migration, numerical modeling, downward fluid flow

Received 11 August 2009; accepted 26 January 2010

Corresponding author: Guoxiang Chi, Department of Geology, University of Regina, Regina, SK, Canada S4S OA2. Email: guoxiang.chi@uregina.ca. Tel: 1-306-585-4583. Fax: 1-306-585-5433.

Geofluids (2010) 10, 334-350

\section{INTRODUCTION}

The Anticosti Basin is a large (approximately 120000 $\mathrm{km}^{2}$ ) Paleozoic sedimentary basin covering the northern part of the Gulf of St. Lawrence, including Anticosti Island (Fig. 1). The preserved succession of the basin consists of Lower Ordovician to Lower Silurian carbonates. Studies by Bertrand (1987, 1990, 1991) indicate that the shales of the Upper Ordovician Macasty Formation contain $>3.5 \%$ total organic carbon (TOC) and have reached the oil (northern part) and gas (southern part) windows. Source rocks equivalent to the Macasty Formation are widespread in other parts of the St. Lawrence Platform (Lavoie et al. 2009). Therefore, it is possible that organic-rich shales are distributed over much of the Anticosti Basin, and large amounts of hydrocarbons may have been generated. Despite the hydrocarbon potential, limited exploration has been carried out in the Anticosti Basin. To date, 13 holes have been drilled on Anticosti Island, which corresponds to one drill hole per $8645 \mathrm{~km}^{2}$ for the basin. Since the discovery of the Port au Port oil field in neighboring western Newfoundland in 1995 (Cooper et al. 2001), much 
(B)

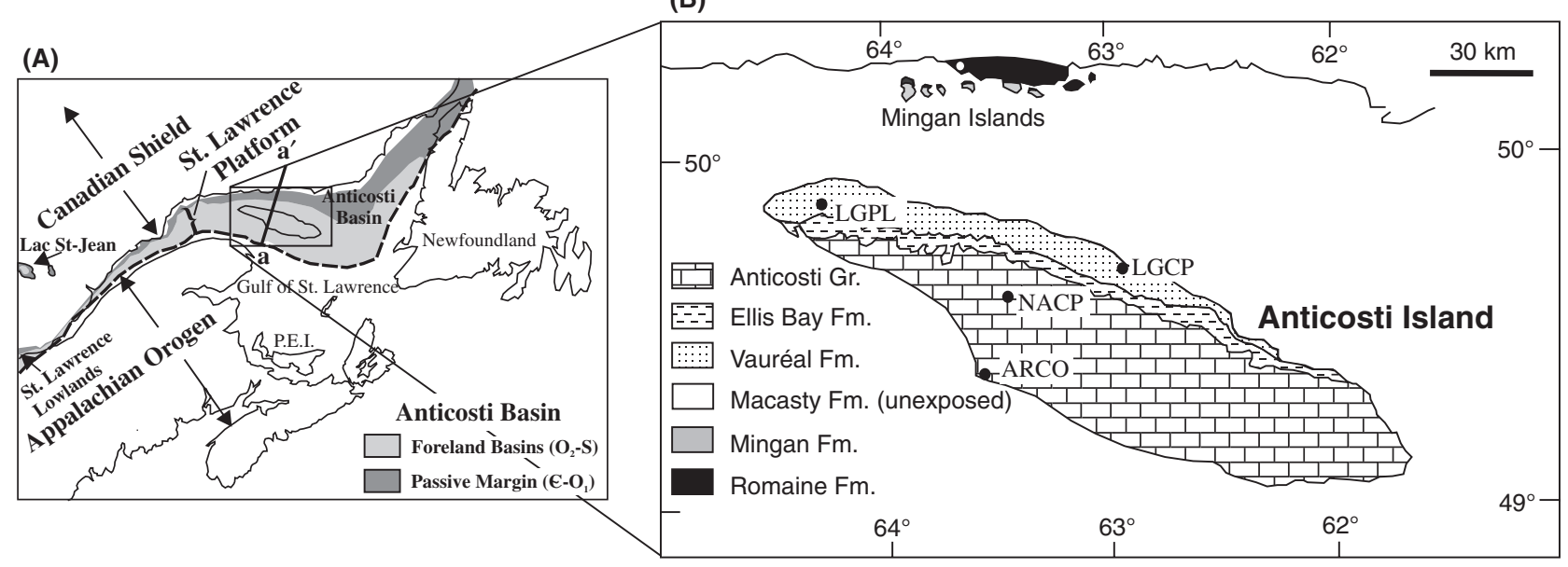

Fig. 1. (A) Regional geologic map of part of eastern Canada (simplified from Sanford 1993; Williams 1995). The dashed line is the Appalachian Structural Front. The Anticosti Basin makes up part of the St. Lawrence Platform, which is shaded. Line a-a' indicates the location of the cross-section in Fig. 2. (B) Geologic map of Anticosti Island (after Bertrand 1987).

attention has been paid to the Anticosti Basin, and a new round of exploration is underway (Lavoie et al. 2009).

Dolostones of the Early Ordovician Romaine Formation in the Anticosti Basin (Figs 1 and 2), a time and faciesequivalent of the reservoir rock in the upper part of the St. George Group in western Newfoundland (Azmy et al. 2008), show significant porosity and evidence of oil migration (Chi \& Lavoie 2001; Lavoie et al. 2005). Dolostones and dolomitized limestones of the Middle Ordovician Mingan Formation above the Romaine Formation have also been shown to be locally porous, representing another potential hydrocarbon reservoir unit (Lavoie et al. 2009).
Both the Romaine and Mingan formations were the targets of recent exploration led by Shell Canada - Encal - Corridor Resources - Hydro-Québec Oil and Gas. The Romaine and Mingan formations lie stratigraphically below the Macasty Formation, and have not been thrusted or reversefaulted into positions above the source rock, although some extensional faulting places the potential source and reservoir rocks in local juxtaposition (Lynch \& Trollope 2001). Therefore, the existence of hydrocarbon reservoirs in the Romaine and Mingan formations depends on whether hydrocarbons generated in the Macasty Formation can migrate downward, in addition to suitable trapping
Fig. 2. Cross-section for numerical modeling. Thickness and stratigraphy were compiled from data in Bertrand (1987, 1990), Williams (1974), and Waldron et al. (1998). Lithology, time interval, and thickness data are in Table 1. The modern erosion surface is mainly based on Bertrand (1987, 1990), and the Mid-Silurian hiatus is based on Waldron et al. (1998). The modern erosion surface is inclined to the north, indicating that there has been more erosion in the north than in the south.

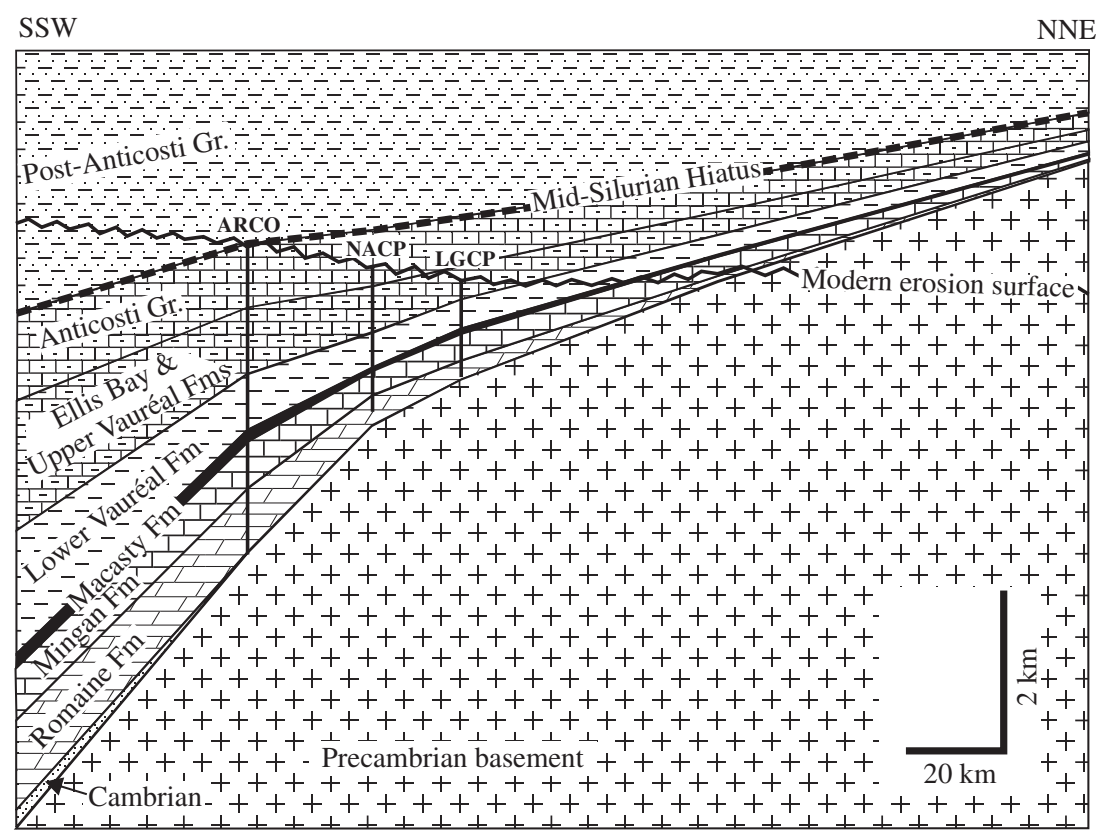


and sealing conditions. The direction of hydrocarbon migration depends on hydraulic potential (Hubbert 1940) or fluid overpressure (a positive difference between actual fluid pressure and hydrostatic pressure), in addition to buoyancy and capillary forces (Hubbert 1953; Garven 1989; Bethke et al. 1991). Therefore, it is important to know the distribution of fluid overpressure throughout the history of the Anticosti Basin in order to evaluate the possibility of hydrocarbons migrating downward from the Macasty Formation to the Mingan and Romaine formations.

Fluid flow in sedimentary basins is typically driven by fluid overpressures related to sediment compaction in the sedimentation stage, and by topographic relief in the uplifting stage (Garven 1989; Bethke et al. 1991), whereas compression and thrusting can provide additional forces near the structural front in foreland basins (Ge \& Garven 1992). In this study, we focus on modeling of fluid overpressures in the sedimentary stage because much of the primary migration of hydrocarbons from source rocks to carrier beds may have taken place during this stage. Topography-driven flow, which is important for secondary migration or redistribution of hydrocarbons, is not studied here. Fluid overpressure during sedimentation is primarily caused by disequilibrium compaction, and by hydrocarbon generation to a lesser extent (Swarbrick et al. 2002). Several studies suggest that hydrocarbon generation can be a major contribution to overpressure development (Bredehoeft et al. 1994; Luo \& Vasseur 1996; Lee \& Williams 2000; McPherson \& Bredehoeft 2001; Hansom \& Lee 2005). We model the distribution of fluid overpressure caused by disequilibrium compaction and oil and gas generation in the Anticosti Basin based on estimated thicknesses, lithologies, sedimentation durations, and TOC contents of different stratigraphic units across the basin. This was performed by numerically solving the compaction, fluid flow, and heat transfer equations as described in Bethke (1985) and equations related to the effect of hydrocarbon generation as modified from Bredehoeft et al. (1994), Lee \& Williams (2000) and Hansom \& Lee (2005). The possibility of downward migration of hydrocarbons is evaluated based on the magnitude of the buoyancy force (upward) and the vertical impelling force related to downward gradient of overpressure (Hubbert 1953).

\section{GEOLOGIC SETTING}

The Anticosti Basin is part of the St. Lawrence Platform developed along the Paleozoic Laurentia continental margin (Sanford 1993). It consists of two sedimentary packages: a Cambrian to Lower Ordovician passive margin succession and a Middle Ordovician to Lower Devonian foreland basin succession (Waldron et al. 1998; Lavoie 2008). The transition from passive margin to foreland basin is marked by an unconformity between the Lower Ordovician Romaine Formation and the Middle Ordovician Mingan Formation (Desrochers \& James 1988). This unconformity is a continent-wide feature (Sauk-Tippecanoe sequences unconformity; Sloss 1963) and its development was enhanced by migration of a tectonic peripheral bulge that marks the onset of Iapetus subduction and the Taconian Orogeny (Jacobi 1981; Knight et al. 1991).

The passive-margin succession unconformably overlies the Precambrian basement, and comprises a thin veneer of Cambrian (?) transgressive siliciclastic sediments followed by Lower Ordovician Romaine Formation (Arenigian). A thick succession of Cambrian sediments is widespread in western Newfoundland and consists of siliciclastic - carbonate rocks of the Lower Cambrian Labrador Group and carbonates of the Middle to Upper Cambrian Port au Port Group (Waldron et al. 1998; Lavoie et al. in press). In the northern part of the Anticosti Basin, Cambrian sediments are absent and the Romaine Formation directly overlies the basement, but Cambrian sediments are inferred to be present south of Anticosti Island (Williams 1974). The Romaine Formation is exposed on the northern edge of the basin (Fig. 1B), and is encountered by drill holes on Anticosti Island (Lavoie et al. 2009). The Romaine Formation is composed of dolostones and dolomitic limestones, with minor sandstones and shales (Desrochers \& James 1988).

The preserved foreland basin succession of the Anticosti Basin consists of (in ascending order) the Middle Ordovician Mingan Formation, the Upper Ordovician Macasty, Vauréal, and Ellis Bay formations, and the Lower Silurian Anticosti Group (Lavoie et al. 2009). The Mingan Formation (Darriwilian to Caradocian) consists of limestones and dolomitic limestones, with minor shales and sandstones. The Macasty Formation and the lower part of the Vauréal Formation (late Caradocian to early Ashgillian) are mainly composed of shales with minor sandstones, whereas the upper part of the Vauréal Formation, the Ellis Bay Formation, and the Anticosti Group (Ashgillian to Llandoverian) are composed of limestones with minor shales and sandstones (Bertrand 1987; Sanford 1993).

Studies of organic matter maturation (Bertrand 1987, 1990 ) indicate that as much as $3.5 \mathrm{~km}$ of sediment was deposited above the Anticosti Group and subsequently eroded. Siliciclastic rocks of the Lower Devonian Clam Bank and Red Island Road formations are preserved in western Newfoundland (Burden et al. 2002; Quinn et al. 2004) and, from seismic correlation, the Clam Bank Formation is interpreted to be present southeast of Anticosti Island (Sanford \& Grant 1990). Waldron et al. (1998) suggested that there was regional, tectonically driven pre-Late Silurian erosion in the foreland basin, followed by further sedimentation from latest Silurian to Early 
Devonian. We infer that the eroded strata in the Anticosti Basin were initially deposited from Late Silurian to Early Devonian.

The Appalachian foreland basin was developed in response to multiple tectonic events (Taconian, Acadian, and Alleghanian) in the Appalachian Orogen (Quinlan \& Beaumont 1984). The foreland basin sedimentation in the Anticosti Basin was largely the result of the Taconian Orogeny (late Darriwilian to early Ashgillian) to the south (Malo 2004; Lavoie 2008). The first thrusting event may have taken place in late Darriwilian to early Caradocian, resulting in formation of tectonic highlands in the Gaspé and the initial foreland basin sedimentation of the Mingan Formation (Malo 2004). Rapid sea-level rise combined with continued foreland subsidence during the late Caradocian led to deposition of the Macasty Formation in the sediment-starved Anticosti Basin (Malo 2004). Renewed thrusting in the Ashgill resulted in rapid deposition, followed by slow sedimentation in the Llandovery (Malo 2004; Long 2007). After a prolonged period of uplifting and erosion in the Anticosti Basin, sedimentation may have resumed from Late Silurian to Early Devonian, in response to the Acadian Orogeny (Lochkovian to Givetian) (Waldron et al. 1998; Burden et al. 2002; Quinn et al. 2004); much of these sediments subsequently eroded after the Acadian Orogeny.

As part of the St. Lawrence Platform, the strata in the Anticosti Basin have not experienced significant tectonic deformation. They strike northwest and dip gently to the southwest (Fig. 1B), with no evidence of folding (Castonguay et al. 2005). Seismic profiles indicate a series of northwest-trending high-angle faults with a downthrown southwest block (Lynch \& Trollope 2001; Lynch \& Grist 2002). These faults primarily affected the lower part of the succession including the Romaine, Mingan, and Macasty formations and to some extent the base of the Vauréal Formation (Lavoie et al. 2009).

\section{PHYSICAL MODEL AND CALCULATION METHODS}

A model cross-section of the Anticosti Basin (Fig. 2) was constructed based on the stratigraphic data compiled by Bertrand (1987). The location of the section is shown by line a-a' in Fig. 1A. The southern end of the section corresponds to the Appalachian structural front (dashed line in Fig. 1A), and the northern end is located north of the erosional edge of the basin. The strata located south of the Appalachian structural front belong to the Appalachian Orogen and are not included in the model.

The model comprises eight hydrostratigraphic units: (1) the Cambrian transgressive veneer, (2) the Romaine Formation, (3) the Mingan Formation, (4) the Macasty Formation, (5) the lower part of the Vauréal Formation, (6) the upper part of the Vauréal Formation and the Ellis Bay Formation, (7) the Anticosti Group, and (8) Upper Silurian to Lower Devonian sediments that have been eroded. The lithology, duration, TOC, and thickness data are in Table 1 . The thickness data in Table 1 are multiplied by a decompaction factor to get initial thickness values before compaction. The decompaction factors for individual hydrostratigraphic units were determined by trail-and-error to achieve the postcompaction thicknesses in Table 1. The lithologic composition of the different hydrostratigraphic units is represented by different combinations of sandstone, shale, and platform carbonates. No lateral changes in lithology are invoked due to lack of data. Thicknesses are controlled by three drill holes (ARCO, NACP, and LGCP), and are extrapolated from isopach maps compiled by Bertrand (1987). The TOC of $5.4 \%$ for the Macasty Formation (Table 1) represents the value before maturation, which was extrapolated from the data of Bertrand (1991). The modern erosion surface (Fig. 2) indicates that much of the northern part of the basin was removed by erosion.

Table 1 Lithology, time interval, TOC, and thickness $(\mathrm{m})$ of hydrostratigraphic units.

\begin{tabular}{|c|c|c|c|c|c|c|c|c|c|}
\hline \multirow[b]{2}{*}{ Unit } & \multirow[b]{2}{*}{ Lithology } & \multirow[b]{2}{*}{$\begin{array}{l}\text { Time interval } \\
\text { (Ma) }\end{array}$} & \multirow[b]{2}{*}{$\begin{array}{l}\text { TOC } \\
(\%)\end{array}$} & \multicolumn{6}{|c|}{ Thickness (m) } \\
\hline & & & & $\begin{array}{l}\text { Basin } \\
\text { center }\end{array}$ & ARCO & NACP & LGCP & $\begin{array}{l}\text { North coast of } \\
\text { St Lawrence Rv }\end{array}$ & $\begin{array}{l}\text { Basin } \\
\text { margin }\end{array}$ \\
\hline Post-Anticosti & $50 \%$ sd $+50 \%$ sh & 424.0 to 386.0 & 0.2 & 3286 & 2410 & 2249 & 2080 & 1632 & 800 \\
\hline Hiatus & & 428.0 to 424.0 & & & & & & & \\
\hline Anticosti Gr & $5 \% \mathrm{sd}+5 \% \mathrm{sh}+90 \% \mathrm{Ims}$ & 439.0 to 428.0 & 0.1 & 1098 & 806 & 707 & 598 & 403 & 200 \\
\hline $\begin{array}{l}\text { Ellis Bay Fm + Upper } \\
\text { Vaureal Fm }\end{array}$ & $5 \% \mathrm{sd}+5 \% \mathrm{sh}+90 \% \mathrm{lms}$ & 441.1 to 439.0 & 0.1 & 1600 & 822 & 547 & 397 & 290 & 140 \\
\hline Lower Vaureal Fm & $5 \% \mathrm{sd}+5 \% \operatorname{lms}+90 \% \mathrm{sh}$ & 443.1 to 441.1 & 0.3 & 1500 & 706 & 485 & 364 & 273 & 130 \\
\hline Macasty Fm & $100 \% \mathrm{sh}$ & 449.7 to 443.1 & 5.4 & 180 & 173 & 28 & 42 & 30 & 15 \\
\hline Mingan Fm & $10 \% \mathrm{sh}+90 \% \mathrm{Ims}$ & 468.6 to 449.7 & 0.2 & 620 & 559 & 340 & 336 & 254 & 60 \\
\hline Romaine Fm & $100 \% \operatorname{lms}$ & 493.0 to 468.6 & 0.1 & 1127 & 783 & 384 & 233 & 64 & 10 \\
\hline Cambrian & $100 \%$ sd & 510.0 to 493.0 & 0.0 & 200 & 0 & 0 & 0 & 0 & 0 \\
\hline
\end{tabular}

sd, sandstone; sh, shale; Ims, limestone; TOC, total organic carbon. 
The total length of the section is $220 \mathrm{~km}$. The model section is divided into 20 evenly distributed columns. The left boundary (south, basin center) is considered a plane of symmetry; no fluid flow or heat transfer occurs across this boundary. The right boundary (north, basin edge) is open to fluid flow. The bottom boundary is closed to fluid flow and subject to a heat flux of $56.3 \mathrm{~mW} \mathrm{~m}^{-2}$ based on a thermal gradient of $26^{\circ} \mathrm{C} \mathrm{km}^{-1}$ derived from organic matter maturation studies (Bertrand 1987, 1990). The upper boundary is open to flow, and has a fixed temperature of $20^{\circ} \mathrm{C}$ based on interpretation that much of the sedimentary succession in the Anticosti Basin was deposited in tropical conditions (Long 2007).

Numerical modeling was carried out to simulate fluid flow and overpressure evolution using the physical model described above. Calculations were made (i) considering only the effect of disequilibrium compaction and heating on fluid overpressure development and (ii) taking into account the additional effect of oil and gas generation.

The thermal expansion coefficient, compressibility coefficient, heat capacity and heat conductivity of fluid and the density, heat capacity and heat conductivity of solid matrix are assumed to be constants (Table 2), adopted from Bethke (1985) and Garven (1985) and summarized in Chi \& Savard (1998). Fluid density and viscosity are calculated from fluid temperatures using the relationships in Bethke (1985) and Bethke et al. (1993). Rock porosity $(\varphi)$ is related to effective depth $\left(z_{\mathrm{e}}\right)$ as described in Bethke (1985):

$\phi=\phi_{0} \mathrm{e}^{-z_{e} b}+\phi_{1}$,

where $\varphi_{0}$ is the porosity at deposition, $\varphi_{1}$ is the irreducible porosity, and $b$ is an empirical parameter (Table 3 ). Permeability $(k)$ is related to porosity by

$\log k_{x}=A \phi+B$

where $k_{x}$ is horizontal permeability and $A$ and $B$ are lithology-dependent constants (Table 3 ). Vertical permeability $\left(k_{z}\right)$ is calculated from horizontal permeability with the ratio being a lithology-dependent constant (Table 3 ).

Table 2 Rock and fluid properties used in the modeling.

\begin{tabular}{|c|c|c|c|}
\hline Property & Value & Unit & Reference \\
\hline \multicolumn{4}{|l|}{ Fluid } \\
\hline Thermal expansion coefficient & $\alpha=5000$ & per ${ }^{\circ} \mathrm{C}$ & (1) \\
\hline Compressibility coefficient & $\beta=4.3 \mathrm{E}-10$ & $\mathrm{~m} \mathrm{~s}^{-2} \mathrm{~kg}^{-1}$ or $\mathrm{Pa}^{-1}$ & (1) \\
\hline Heat capacity & $C_{f}=4200$ & $\mathrm{~J} \mathrm{~kg}^{-1}$ per ${ }^{\circ} \mathrm{C}$ & (1) \\
\hline Heat conductivity & $K_{\mathrm{f}}=0.63$ & $\mathrm{~W} \mathrm{~m}^{-1}$ per ${ }^{\circ} \mathrm{C}$ & $(2)$ \\
\hline \multicolumn{4}{|l|}{ Solid matrix } \\
\hline Density & $\rho_{r}=2700$ & $\mathrm{~kg} \mathrm{~m}^{-3}$ & (1) \\
\hline Heat capacity & $C_{r}=840$ & $\mathrm{~J} \mathrm{~kg}^{-1}$ per ${ }^{\circ} \mathrm{C}$ & (1) \\
\hline Heat conductivity & $K_{\mathrm{r}}=2.5$ & $\mathrm{~W} \mathrm{~m}^{-1}$ per ${ }^{\circ} \mathrm{C}$ & (2) \\
\hline
\end{tabular}

References: (1) Bethke (1985); (2) Garven (1985).
Table 3 Constants related to porosity and permeability calculations.

\begin{tabular}{lcclcccc}
\hline Lithology & $\varphi_{0}$ & $\varphi_{1}$ & $b\left(\mathrm{~km}^{-1}\right)$ & $A^{*}$ & $B^{*}$ & $k_{x} / k_{z}$ & Reference \\
\hline Sandstone & 0.40 & 0.10 & 0.50 & 15 & -3 & 2.5 & $(1)$ \\
Shale & 0.55 & 0.05 & 0.85 & 8 & -8 & 10 & $(1)$ \\
Limestone & 0.40 & 0.05 & 0.55 & 6 & -4 & 2.5 & $(2)$ \\
\hline
\end{tabular}

References: (1) Harrison \& Summa (1991); (2) Kaufman (1994).

* Permeability calculated from $A$ and $B$ is in darcies (1 darcy $=9.869233 \times 10^{-13} \mathrm{~m}^{2}$ ).

The porosity-depth and porosity-permeability relationship parameters are adopted from Harrison \& Summa (1991) for sandstone and shale, and from Kaufman (1994) for limestone (Table 3), as summarized in Chi \& Savard (1998). Sensitivity studies were carried out by varying these parameters. The vertical and horizontal permeabilities of the rocks are calculated as the harmonic and geometric means of the lithologic components respectively.

The governing equations and numerical procedures are similar to those in previous studies (Bethke 1985; Bethke et al. 1993; Chi \& Savard 1998; Lee \& Williams 2000; Chi 2001; Hansom \& Lee 2005) and are not described here. However, calculation of the effect of hydrocarbon generation on overpressure development, and of the fractions of oil and gas generated, requires some elaborations in addition to those by Lee \& Williams (2000) and Hansom \& Lee (2005). The flow equation used in the numerical modeling, derived from the general governing equation of Bethke (1985) and with consideration of the effect of oil and gas generation (Hansom \& Lee 2005), is:

$$
\begin{gathered}
{\left[V_{\mathrm{b}} \phi \beta+\frac{V_{\mathrm{b}}}{(1-\phi)} b\left(\phi-\phi^{\theta}\right) \frac{1}{\left(\rho_{\mathrm{sm}}-\rho\right)}\right] \frac{\partial \psi}{\partial t}-\frac{1}{\rho}} \\
{\left[\frac{\partial}{\partial x}\left(\frac{\rho k_{x} \Delta z}{\mu} \frac{\partial \psi}{\partial x}\right) \Delta x+\frac{\partial}{\partial z}\left(\frac{\rho k_{z} \Delta x}{\mu} \frac{\partial \psi}{\partial z}\right) \Delta z\right]} \\
=-V_{\mathrm{b}} V_{z m}\left[\phi \rho \beta+\frac{1}{(1-\phi)} b\left(\phi-\phi^{\theta}\right)\right] \\
+\phi V_{\mathrm{b}} \alpha \frac{\partial T}{\partial t}+q_{\mathrm{o}}+q_{\mathrm{g}},
\end{gathered}
$$

where $V_{\mathrm{b}}$ is the volume of a finite difference block, $\phi$ is the porosity, $\phi^{\theta}$ is the porosity in the intermediate time step, $\beta$ is the coefficient of compressibility of pore fluid, $b$ is a coefficient related to porosity decrease with depth, $\rho_{\mathrm{sm}}$ is density of fluid-saturated medium, $\rho$ is the density of fluid, $\psi$ is the fluid overpressure, $t$ is the time, $x$ is the horizontal coordinate, $z$ is the vertical coordinate, $k_{x}$ is the horizontal permeability, $k_{z}$ is the vertical permeability, $\mu$ is the fluid dynamic viscosity, $\Delta x$ and $\Delta z$ are the horizontal and vertical size of the finite difference block, $V_{z m}$ is the settling velocity of a block, $\alpha$ is the coefficient of thermal expansion of the pore fluid, $T$ is temperature, and $q_{0}$ and $q_{\mathrm{g}}$ are source terms for oil and gas generation respectively. This equation is solved, together with the compaction equation and the heat transfer equation, for overpressure 
$(\psi)$, temperature $(T)$, and porosity $(\phi)$. The values of $q_{\mathrm{o}}$ and $q_{\mathrm{g}}$ are related to density changes from kerogen to oil and from oil to gas as follows:

$q_{\mathrm{o}}=\frac{g \mathrm{~d} X_{\mathrm{o}}}{\mathrm{d} t}\left(\frac{\rho_{\mathrm{k}}}{\rho_{\mathrm{o}}}-1\right) X_{\mathrm{k}} V_{\mathrm{b}}$

$q_{\mathrm{g}}=\frac{\mathrm{d} X_{\mathrm{g}}}{\mathrm{d} t}\left(\frac{\rho_{\mathrm{o}}}{\rho_{\mathrm{g}}}-1\right) X_{\mathrm{k}} X_{\mathrm{o}} V_{\mathrm{b}}$,

where $X_{\mathrm{o}}$ and $X_{\mathrm{g}}$ are fractions of oil and gas generated (out of the total capacity for oil and gas generation respectively); $t$ is the time; $\rho_{\mathrm{k}}, \rho_{\mathrm{o}}$, and $\rho_{\mathrm{g}}$ are the density of kerogen, oil, and gas respectively; $X_{\mathrm{k}}$ is the volume fraction of kerogen in sedimentary rocks; and $V_{\mathrm{b}}$ is the volume of the finite difference block. In this study, the density of kerogen was assumed to be $1.45 \mathrm{~g} \mathrm{~cm}^{-3}$ (Lee \& Williams 2000), the density of oil was assumed to be $0.9 \mathrm{~g} \mathrm{~cm}^{-3}$ (Speight 2006), and the density of gas depends on temperature and pressure and was calculated from an equation of state of Duan et al. (1992), following Hansom \& Lee (2005). The volume fractions of kerogen were calculated from the TOC wt $\%$ values. The kerogens of the Macasty Formation belong to type II (Bertrand 1991), which may contain 68 to $74 \mathrm{wt} \% \mathrm{C}$ (Bordenave 1993). Assuming an average of $71 \mathrm{wt} \% \mathrm{C}$ in the kerogens and a density of $1.45 \mathrm{~g} \mathrm{~cm}^{-3}$ and $2.5 \mathrm{~g} \mathrm{~cm}^{-3}$ for the kerogens and rocks respectively, $X_{\mathrm{k}}$ can be calculated from TOC as follows:

$X_{\mathrm{k}}=\frac{3.52 \mathrm{TOC} / 100}{1.45+1.48 \mathrm{TOC} / 100}$

The $X_{\mathrm{o}}$ and $X_{\mathrm{g}}$ values are related to the kinetics of kerogen-to-oil and oil-to-gas conversion. Because oil and gas generation are considered as first-order reactions, the change of kerogen fraction $(V)$ with time $(t)$ can be expressed as follows (Bredehoeft et al. 1994):

$\frac{\mathrm{d} V}{\mathrm{~d} t}=-k V$

or

$\frac{\mathrm{d} V}{V}=-k \mathrm{~d} t$

where $k$ is the rate of oil or gas generation, which can be calculated according to the Arrhenius model:

$k=A \mathrm{e}^{-E / R T_{k}}$

where $A$ is the pre-exponential factor $\left(\mathrm{h}^{-1}\right), E$ is the activation energy $\left(\mathrm{KJ} \mathrm{mol}^{-1}\right), \quad R$ is the gas constant $\left(8.31432 \mathrm{~J} \mathrm{~K}^{-1} \mathrm{~mol}^{-1}\right)$, and $T_{k}$ is the absolute temperature $(\mathrm{K})$. In the numerical model, the value of $k$ for a given time step can be considered as constant, therefore, integration of Eq. (8) over a time step gives: $\ln \frac{V}{V^{\mathrm{p}}}=-k \Delta t$

or

$V=V^{\mathrm{p}} \mathrm{e}^{-k \Delta t}$

where $V^{\mathrm{p}}$ is the $V$ value of the previous time step. The fraction of oil or gas generated $(X)$ is complementary to $V$ (the remaining fraction of oil or gas) (i.e. $X=1-V$ ), therefore we have:

$X=1-\left(1-X^{\mathrm{p}}\right) \mathrm{e}^{-k \Delta t}$,

where $X^{\mathrm{p}}$ is the $X$ value in the previous time step. Both $X_{\mathrm{o}}$ and $X_{\mathrm{g}}$ are calculated in the same way, although they have different $k$ values.

The timing and rate of hydrocarbon generation are controlled by the pre-exponential factor $A$ and the activation energy $E$ in the Arrhenius equation, which differ significantly for different types of kerogens (Peters et al. 2006). For type II kerogens in marine siliciclastic rocks like the Macasty Formation (Bertrand 1991), an $A_{\mathrm{o}}$ value of $8.14 \times 10^{13} / \mathrm{s}$ or $2.92 \times 10^{17} \mathrm{~h}^{-1}$ and an $E_{\mathrm{o}}$ value of $215.2 \mathrm{~kJ} \mathrm{~mol}^{-1}$ are adopted from Pepper \& Corvi (1995) (Table 4$). A_{\mathrm{g}}$ and $E_{\mathrm{g}}$ values for oil-to-gas cracking are set to be $3.6 \times 10^{16} \mathrm{~h}^{-1}$ and $230 \mathrm{~kJ} \mathrm{~mol}^{-1}$ respectively, based on data for intra-source oil cracking as summarized in Pepper \& Dodd (1995) (Table 4). Sensitivity studies were carried out by varying the kinetic parameters.

The program used for the numerical modeling was first written in FORTRAN by Chi \& Savard (1998) and then modified and written in C++ by Chi (2001). Further modifications were made in the course of the present study to account for the effect of hydrocarbon generation on overpressure development as described earlier. The program is similar to Basin2 ${ }^{\mathrm{TM}}$ (Bethke et al. 1993) for overpressure calculation; the latter has many other functions but does not include hydrocarbon generation in its current released version. Modeling results obtained with our program without hydrocarbon generation are similar to those obtained with Basin $2^{\mathrm{TM}}$.

Table 4 Hydrocarbon properties and kinetic parameters used in the modeling.

\begin{tabular}{llll}
\hline Parameter & Value & Unit & Reference \\
\hline Kerogen density & 1450 & $\mathrm{~kg} \mathrm{~m}^{-3}$ & $(1)$ \\
Oil density & 900 & $\mathrm{~kg} \mathrm{~m}^{-3}$ & $(2)$ \\
Kerogen (type-II)-to-oil conversion & & \\
$\quad A_{\mathrm{o}}$ & $2.92 \times 10^{17}$ & $\mathrm{~h}^{-1}$ & $(3)$ \\
$E_{\mathrm{o}}$ & 215.2 & $\mathrm{~kJ} \mathrm{~mol}^{-1}$ & $(3)$ \\
Oil-to-gas conversion & & & \\
$A_{\mathrm{g}}$ & $3.6 \times 10^{16}$ & $\mathrm{~h}^{-1}$ & $(4)$ \\
$E_{\mathrm{g}}$ & 230 & $\mathrm{~kJ} \mathrm{~mol}^{-1}$ & $(4)$ \\
\hline
\end{tabular}

References: (1) Lee \& Williams (2000); (2) Speight (2006); (3) Pepper \& Corvi (1995); (4) Pepper \& Dodd (1995). 


\section{SIMULATION RESULTS}

\section{Overpressures caused by disequilibrium compaction}

Modeling of fluid flow without hydrocarbon generation was carried out by assigning $0 \%$ TOC to all hydrogeologic units. The simulation results indicate that significant fluid overpressures caused by disequilibrium compaction developed during certain stages of basin evolution (Fig. 3). The overpressure values were highest in the basin center in the lower part of the Vauréal Formation, and decreased upward, downward, and laterally toward the basin margin (Fig. 3).

The evolution of fluid overpressures in different strata at different times and different locations in the basin is highlighted in Figs 3 and 4. At the basin center (Figs 3 and $4 \mathrm{~A}$ ), fluid pressures were close to hydrostatic values from Cambrian to the end of deposition of the Mingan Formation $(449.7 \mathrm{Ma})$; fluid overpressures gradually increased during deposition of the Macasty, Vauréal, and Ellis Bay formations and reached maximum values at the end of the Ellis Bay Formation (439 Ma), when sedimentation rate
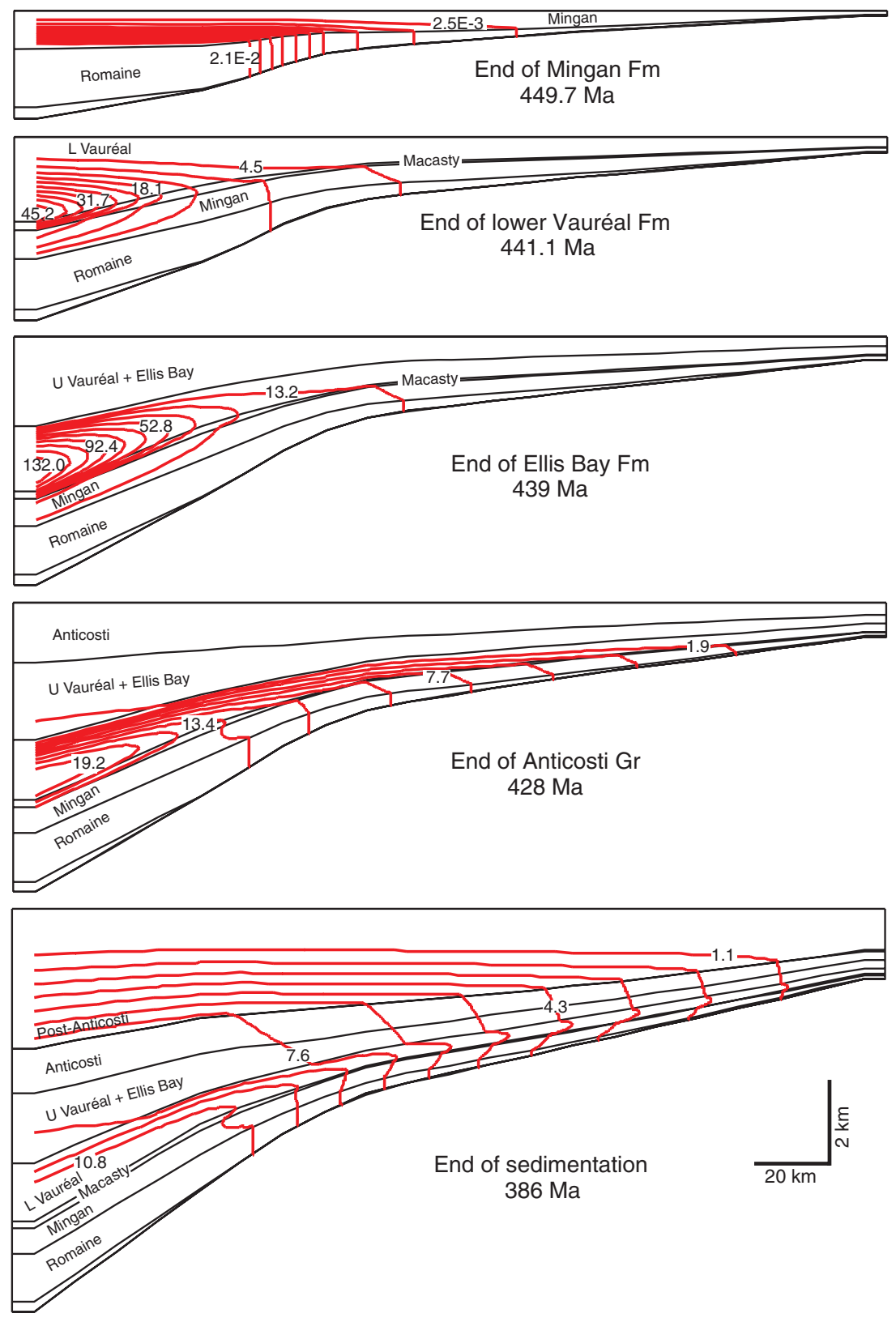

Fig. 3. Calculated fluid overpressures (bars) resulting from sediment compaction in the Anticosti Basin at the end Mingan Formation (449.7 Ma), lower Vauréal Formation (441.1 Ma), Ellis Bay Formation (439 Ma), Anticosti Group (428 Ma), and post-Anticosti Group (386 Ma) sedimentation. 


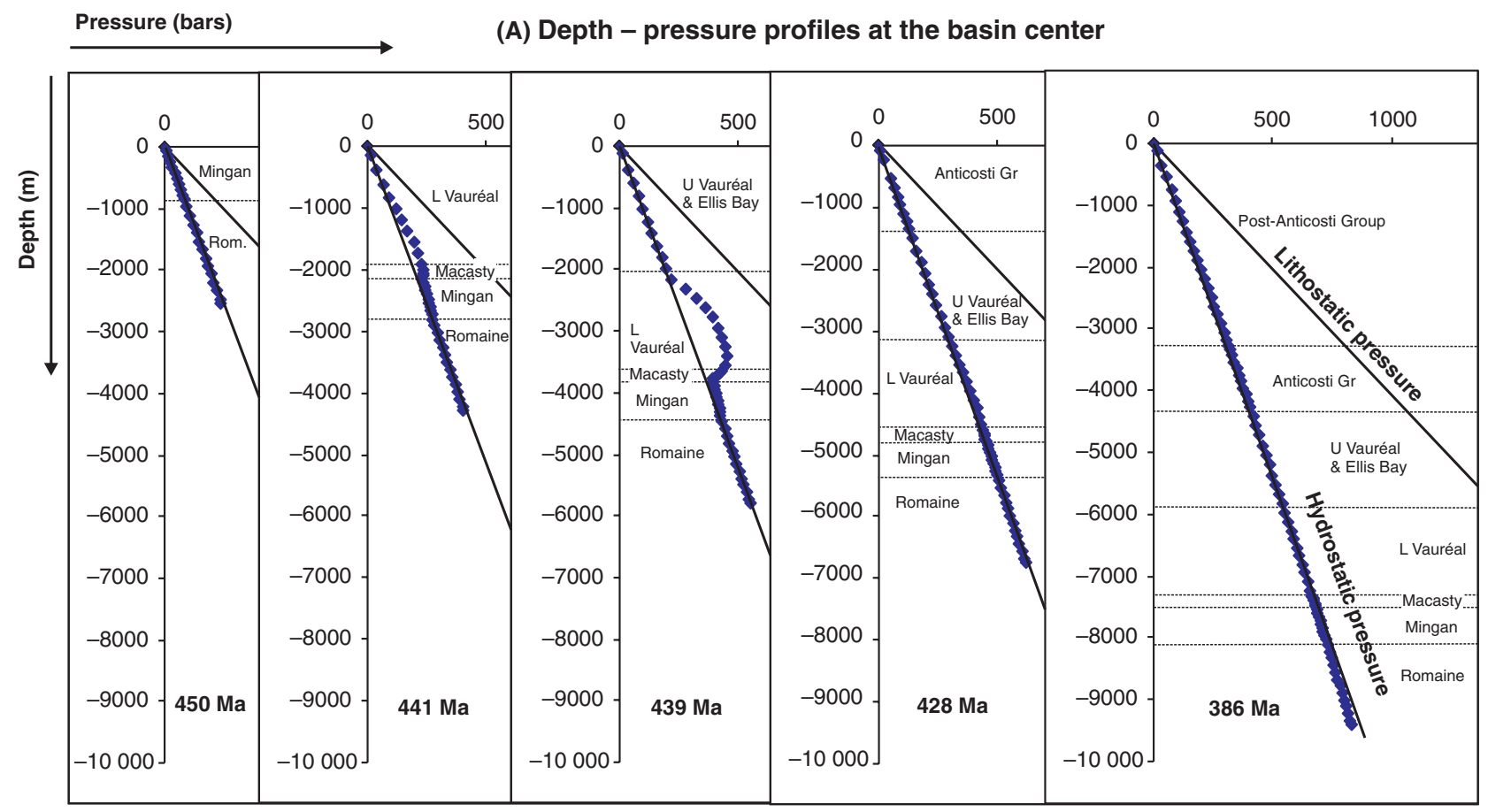

Pressure (bars)

(B) Depth - pressure profiles in the middle of the section

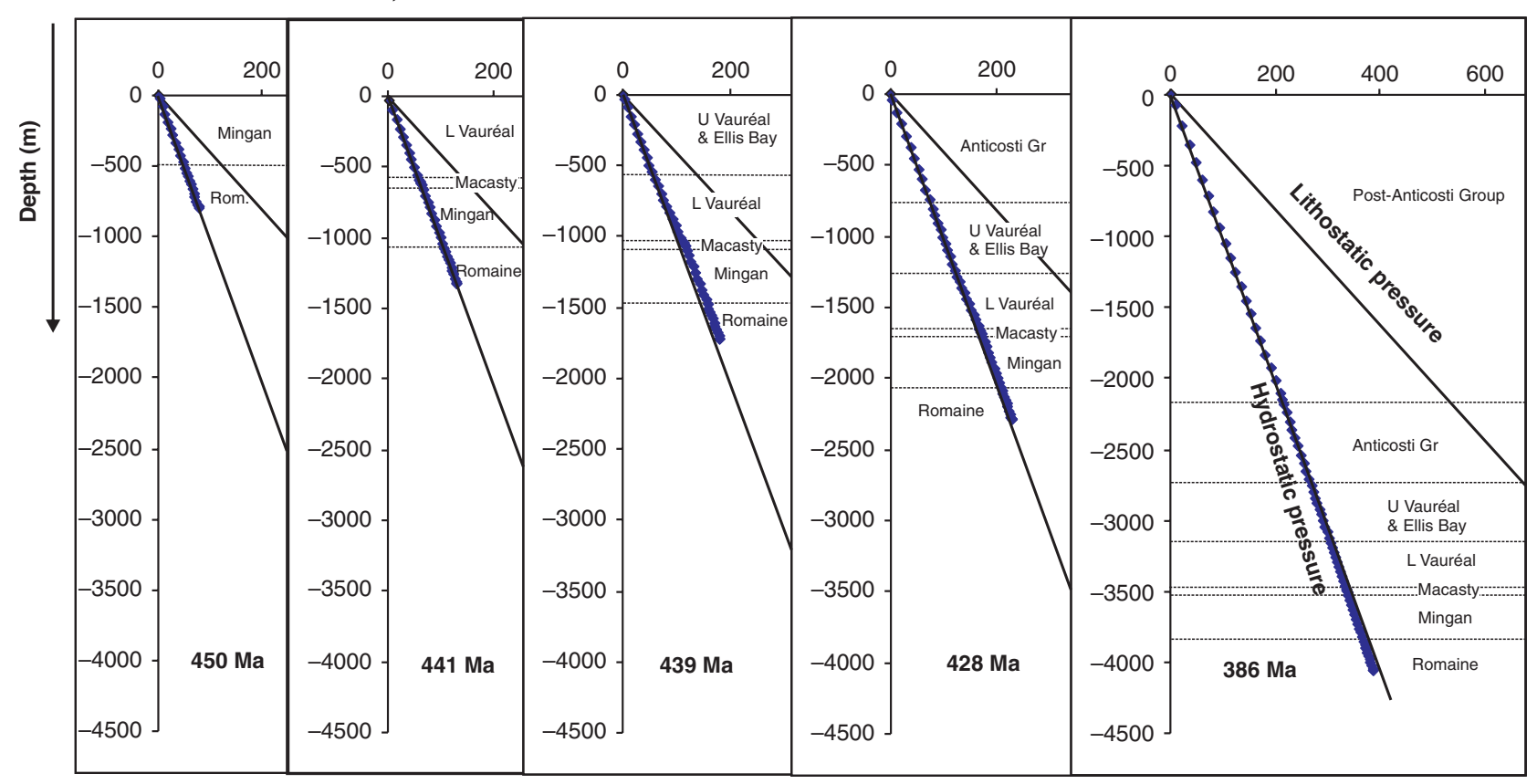

Fig. 4. Calculated pressure-depth profiles in different stages of the basin evolution for the compaction-only model: (A) at the basin center, and (B) at the middle of the section ( $99 \mathrm{~km}$ from basin center). The hydrostatic and lithostatic lines were constructed based on constant fluid and solid densities of 1 and $2.5 \mathrm{~g} \mathrm{~cm}^{-3}$ respectively.

was the highest. A strongly overpressured core developed above the Macasty Formation (Fig. 3), which continued to be present during sedimentation of the Anticosti Group, although overpressure values gradually decreased. By the end of sedimentation in the basin $(386 \mathrm{Ma})$, only minor amounts of overpressure remained. In shallower parts of the basin, in contrast, fluid pressures remained close to hydrostatic values throughout basin history, except during 

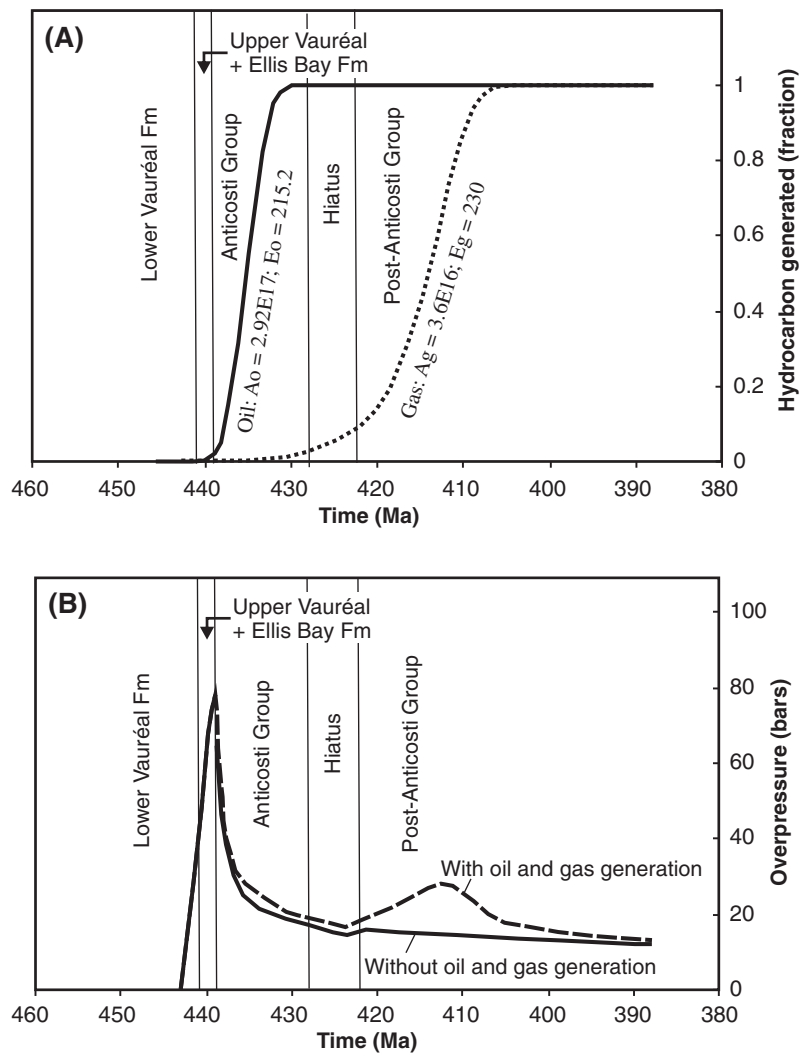

Fig. 5. Calculated evolution of oil and gas generation and overpressure in the Macasty Formation at the basin center. (A) Fraction of oil and gas generated; (B) Fluid overpressure, with and without hydrocarbon generation. deposition of the Vauréal and Ellis Bay formations (Fig. 4B).

\section{Overpressures related to hydrocarbon generation}

Simulations of fluid overpressure based on petroleum generation plus disequilibrium compaction produced almost identical results as the compaction-only models for the period of time from Cambrian to the end of the Ellis Bay Formation, as illustrated by fluid overpressure in the Macasty Formation at the basin center (Fig. 5). This is consistent with the timing of hydrocarbon generation, as significant oil generation did not start until the beginning of the Anticosti Group (Fig. 5A). After this point, fluid overpressure is slightly higher than in the case of no hydrocarbon generation (Fig. 5B). Fluid overpressure started to increase after $424 \mathrm{Ma}$ (Fig. 5B), which coincides with the start of gas generation (Fig. 5A), peaked at $412 \mathrm{Ma}$, and then decreased with time again (Fig. 5B). The calculations have not taken into account the effect of relative permeability decrease (due to presence of hydrocarbon phases) on fluid overpressure, and therefore the results should be interpreted as the minimum effect of hydrocarbon generation on fluid overpressure.

At the end of Anticosti Group sedimentation (428 Ma), the Macasty Formation in the central part of the basin was at the end of the oil window (Fig. 5). Fluid overpressures were slightly higher than in the compaction-only model, and the overpressure distribution almost identical (compare
Fluid overpressure (bars)

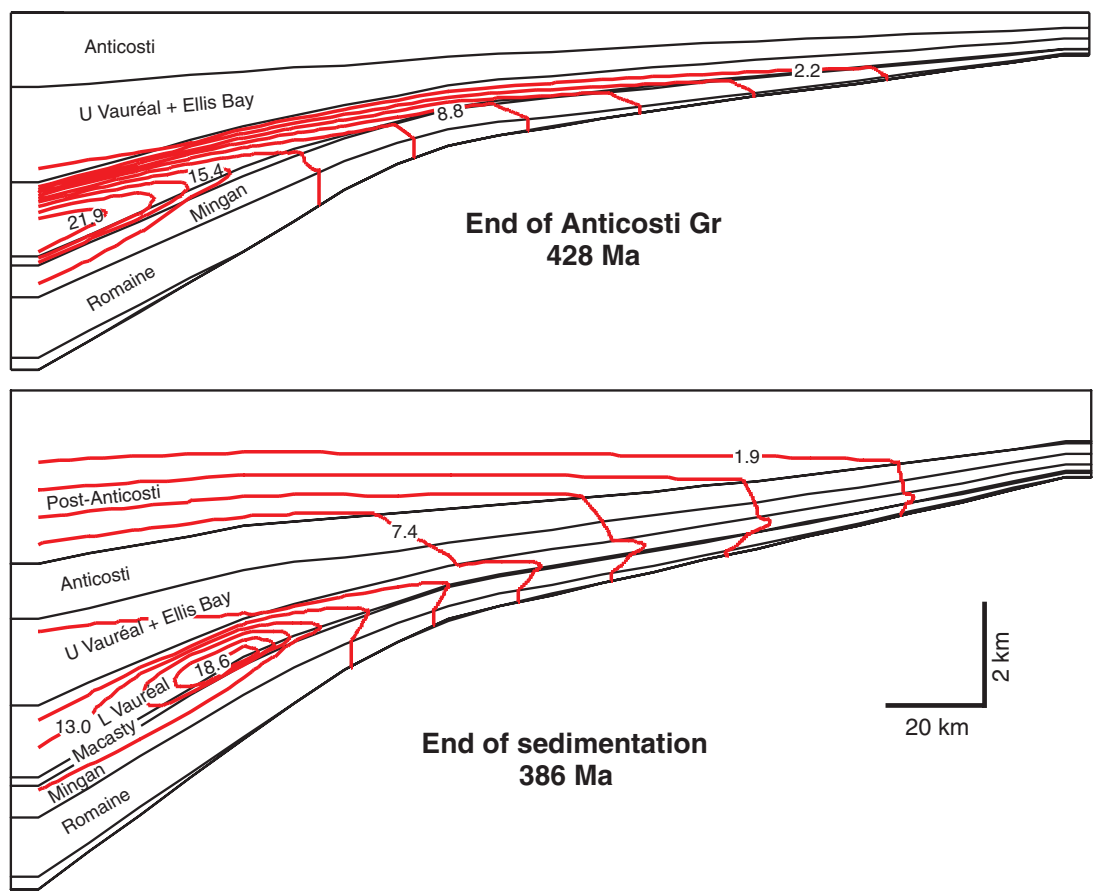

Fig. 6. Calculated fluid overpressures at the end of Anticosti Group (428 Ma) and basin sedimentation (380 Ma), with both disequilibrium compaction and hydrocarbon generation considered in overpressure calculation. 
Fig. 7. Calculated temperatures and oil and gas windows at the end of the Anticosti Group $(428 \mathrm{Ma})$ and the end of basin sedimentation (380 Ma), with both disequilibrium compaction and hydrocarbon generation considered in overpressure calculation.
Temperature $\left({ }^{\circ} \mathrm{C}\right)$

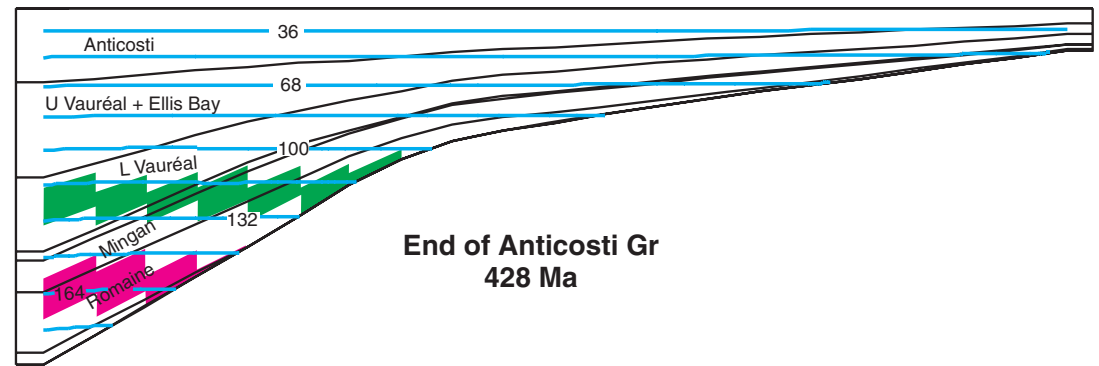



Figs 3 and 6 at $428 \mathrm{Ma}$ ). By the end of sedimentation in the basin $(386 \mathrm{Ma})$, the Macasty Formation had passed beyond the gas window at the basin center, and was in the gas window or oil window further north (Fig. 7). A fluid overpressure core developed in the lower Vauréal Formation north of the basin center (Fig. 6), where the Macasty and the lower Vauréal formations were in the gas window (Fig. 7). This overpressure core is much more prominent than in the compaction-only model (compare Figs. 3 and 6 at $386 \mathrm{Ma})$.

\section{Sensitivity studies}

Previous studies have shown that fluid overpressure related to disequilibrium compaction is sensitive to rock permeability, and permeability values for a given lithology typically vary over two orders of magnitude (Harrison \& Summa 1991) or more. Simulations of fluid overpressure caused by disequilibrium compaction in the Anticosti Basin were carried out with sandstone, shale, and limestone permeabilities one order of magnitude higher and lower than those presented above. Thus, the permeability (in darcies) was varied from $\log k_{x}=15 \phi-4$ to $\log k_{x}=15 \phi-2$ for sandstone, $\log k_{x}=8 \phi-9$ to $\log k_{x}=8 \phi-7$ for shale, and from $\log k_{x}=6 \phi-5$ to $\log k_{x}=6 \phi-3$ for limestone (see eqn 2 and Table 3 ). Fluid overpressure increased significantly with decreasing permeability, as illustrated by the overpressure profile at the basin center (Fig. 8). At the end of Ellis Bay Formation sedimentation (439 Ma), the maxi- mum fluid overpressure is 19.9 bars for the higher permeability case, 145.2 bars for the intermediate permeability case, and 292.4 bars for the lower permeability case (Fig. 8A). The maximum fluid overpressure is located in the lower Vauréal Formation for the higher and intermediate permeability cases, and in the Macasty Formation for the lower permeability case (Fig. 8A). At $386 \mathrm{Ma}$, the maximum fluid overpressure diminishes to 1.8 and 11.9 bars for the higher and intermediate permeability cases respectively, and to 64.8 bars for the lower permeability case (Fig. 8B). The maximum overpressure is located in the lower Vauréal Formation for the intermediate and low permeability cases (Fig. 8B).

Kinetic parameters of kerogen-to-oil conversion can also vary over a wide range of values (Peters et al. 2006). For type II kerogens, the calculated fractional conversions based on the optimal values of Pepper \& Corvi (1995) $\left(A_{\mathrm{o}}=2.92 \times 10^{17} \mathrm{~h}^{-1} ; E_{\mathrm{o}}=215.2 \mathrm{~kJ} \mathrm{~mol}^{-1}\right.$, Table 4) lie in the middle of a range associated with $A_{\mathrm{o}}$ from $3.11 \times 10^{16}$ to $5.48 \times 10^{17} \mathrm{~h}^{-1}$ and $E_{\mathrm{o}}$ from 209.2 to $230.1 \mathrm{~kJ} \mathrm{~mol}^{-1}$ respectively (Peters et al. 2006). According to Pepper \& Dodd (1995), the kinetic parameters related to oil-to-gas conversion also vary considerably, from $A_{\mathrm{g}}=3.6 \times 10^{15} \mathrm{~h}^{-1}$ and $E_{\mathrm{g}}=225.9 \mathrm{~kJ} \mathrm{~mol}^{-1}$, to $A_{\mathrm{g}}=1.08 \times 10^{18} \mathrm{~h}^{-1}$ and $E_{\mathrm{g}}=238.6 \mathrm{~kJ} \mathrm{~mol}^{-1}$. Two sets of sensitivity simulations were carried out, one assuming fixed oil-to-gas conversion parameters (Table 4) and varying kerogen-to-oil parameters, the other assuming fixed kerogen-to-oil conversion parameters (Table 4) and 
(A)



(B)



Fig. 8. Calculated overpressure-depth profiles at the basin center at (A) 439 Ma and (B) 386 Ma - sensitivity studies showing the effect of varying rock permeability.
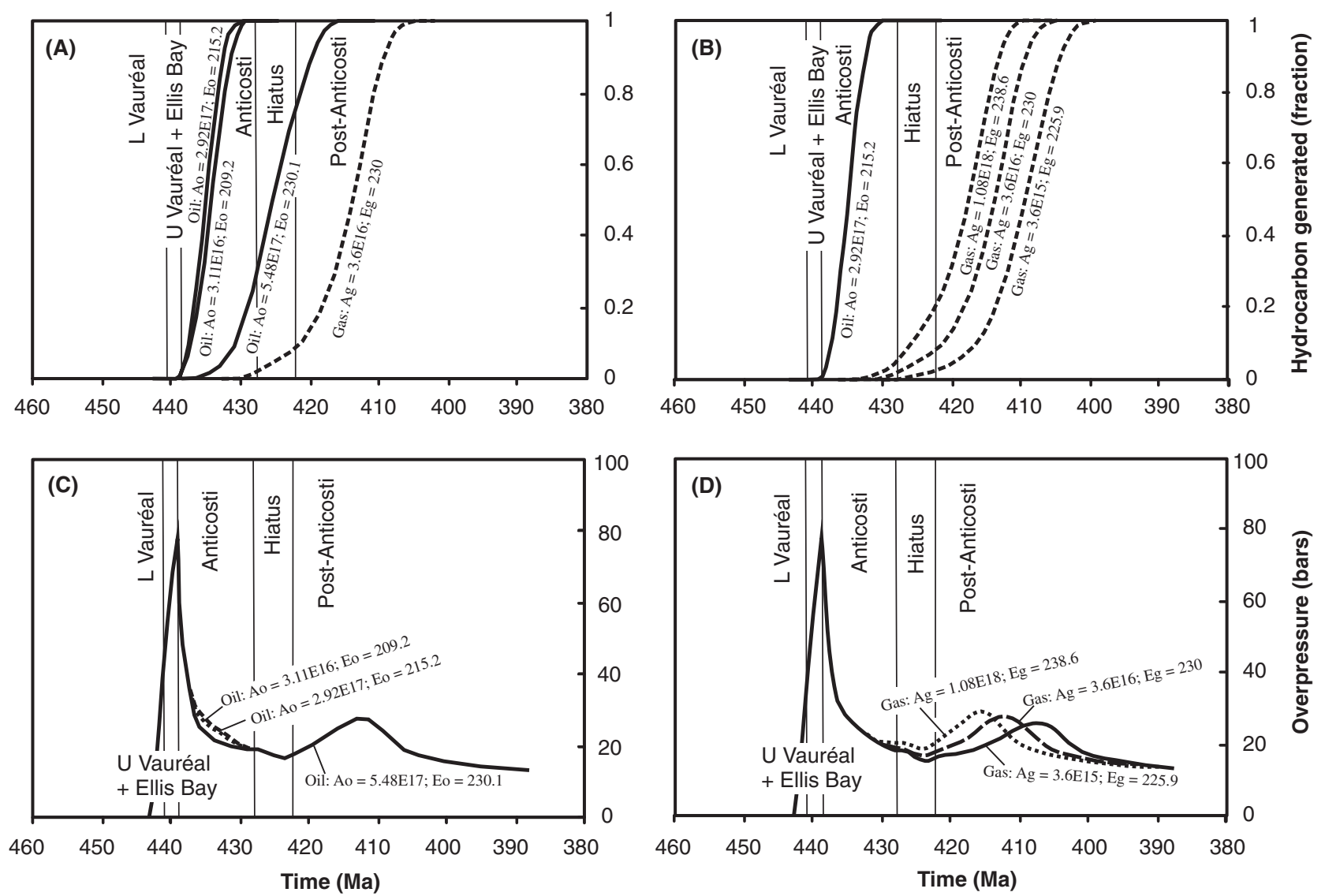

Fig. 9. Sensitivity studies showing the effect of kinetic parameters on timing of oil and gas generation (A and B) and fluid overpressure development (C and D) in the Macasty Formation at the basin center. (A) and (C) assume a fixed set of gas generation kinetic parameters (Table 4) and varying oil generation parameters (Table 4), whereas (B) and (D) assume a fixed set of oil generation kinetic parameters and varying gas generation parameters. 
varying oil-to-gas conversion parameters. Simulation results indicate that varying the kerogen-to-oil kinetic parameters significantly changes the timing of oil generation (Fig. 9A), but has minor effect on fluid overpressure (Fig. 9C). Similarly, varying the oil-to-gas conversion kinetic parameters changes the timing of gas generation (Fig. 9B). The effect on the magnitude of fluid overpressure is minor, but the timing of the second fluid overpressure peak related to gas generation is significantly different for the different oil-togas conversion parameters (Fig. 9D).

\section{Impelling force of oil and gas migration}

According to Hubbert (1953), the impelling force of hydrocarbon (oil or gas) migration $\left(E_{\mathrm{HC}}\right)$ is determined by a combination of buoyancy force and the impelling force of water $\left(E_{\mathrm{W}}\right)$, and can be expressed as:

$E_{\mathrm{HC}}=\frac{\rho_{\mathrm{HC}}-\rho_{\mathrm{W}}}{\rho_{\mathrm{HC}}} g+\frac{\rho_{\mathrm{W}}}{\rho_{\mathrm{HC}}} E_{\mathrm{W}}$

where $\rho_{\mathrm{HC}}$ is the density of oil or gas, $\rho_{W}$ is the density of water, and $g$ is the gravity. The impelling force of water flow is related to fluid overpressure $(\psi)$ by

$E_{\mathrm{W}}=-\frac{1}{\rho_{\mathrm{W}}} \nabla \Psi$

The vertical impelling force of hydrocarbon migration can then be written as

$E_{\mathrm{HC}}=\frac{\rho_{\mathrm{HC}}-\rho_{\mathrm{W}}}{\rho_{\mathrm{HC}}} \mathfrak{g}-\frac{1}{\rho_{\mathrm{HC}}} \frac{\partial \Psi}{\partial z}$.
The first term reflects the buoyancy force, and the second term is the impelling force of water.

A calculation of the impelling force for oil and gas generated in the Macasty Formation was carried out for the end of the Anticosti Group (428 Ma) and the end of sedimentation of the basin (386 Ma), and the results are listed in Table 5 . The impelling force of water is calculated based on the difference between the maximum overpressure (in the Lower Vauréal Formation) and the overpressure at the base of the Macasty Formation. At $428 \mathrm{Ma}$, the Macasty Formation within $33 \mathrm{~km}$ north of the basin center has entered or just passed the oil window (Figs 5A and 7). The downward vertical impelling force for water is from -1.18 to $-1.67 \mathrm{~m} \mathrm{~s}^{-2}$, which is stronger than the upward buoyancy force of 0.43 to $0.58 \mathrm{~m} \mathrm{~s}^{-2}$. As a result, the combined impelling force for oil is negative (downward; Table 5). At $386 \mathrm{Ma}$, the Macasty Formation was in the gas window in the area $33-55 \mathrm{~km}$ from basin center and in the oil window $77-132 \mathrm{~km}$ north of the basin center (Fig. 7). For oil, the buoyancy force ranges from 0.48 to $0.62 \mathrm{~m} \mathrm{~s}^{-2}$, and the vertical impelling force for water is -0.05 to $-0.25 \mathrm{~m} \mathrm{~s}^{-2}$ (Table 5 ). For gas, the buoyancy force ranges from 38.83 to $42.67 \mathrm{~m} \mathrm{~s}^{-2}$, and the impelling force for water is from -1.21 to $1.29 \mathrm{~m} \mathrm{~s}^{-2}$ (Table 5). The combined vertical impelling forces are consistently upward and range from 0.30 to $0.43 \mathrm{~m} \mathrm{~s}^{-2}$ for oil and from 37.62 to $41.38 \mathrm{~m} \mathrm{~s}^{-2}$ for gas (Table 5 ).

\section{DISCUSSION: IMPLICATIONS FOR HYDROCARBON MIGRATION}

The source rock of the Macasty Formation is located in the lower part of the sedimentary succession in the Anticosti Basin (Fig. 2) and thermal maturation studies (Bertrand $1987,1990,1991)$ indicate burial to the oil window

Table 5 Vertical impelling forces for hydrocarbons generated in the Macasty Formation.

\begin{tabular}{|c|c|c|c|c|c|}
\hline $\begin{array}{l}\text { Time } \\
\text { (Ma) }\end{array}$ & $\begin{array}{l}\text { Location (distance } \\
\text { from basin center), km }\end{array}$ & $\begin{array}{l}\text { Oil or } \\
\text { gas }\end{array}$ & $\begin{array}{l}\text { Buoyancy force acting } \\
\text { on hydrocarbons }\left(\mathrm{m} \mathrm{s}^{-2}\right) \\
A=\frac{\rho_{\mathrm{HC}}-\rho_{\mathrm{W}}}{\rho_{\mathrm{HC}}} \mathfrak{g}\end{array}$ & $\begin{array}{l}\text { Vertical impelling force } \\
\text { caused by overpressure } \\
\text { gradient }\left(\mathrm{m} \mathrm{s}^{-2}\right) \\
B=-\frac{1}{\rho_{\mathrm{HC}}} \frac{\Delta \Psi}{\Delta z}\end{array}$ & $\begin{array}{l}\text { Combined vertical } \\
\text { impelling force acting } \\
\text { on hydrocarbons }\left(\mathrm{m} \mathrm{s}^{-2}\right) \\
C=A+B\end{array}$ \\
\hline \multirow[t]{4}{*}{428} & 0 & Oil & 0.43 & -1.33 & -0.90 \\
\hline & 11 & Oil & 0.48 & -1.56 & -1.08 \\
\hline & 22 & Oil & 0.53 & -1.67 & -1.14 \\
\hline & 33 & Oil & 0.58 & -1.18 & -0.60 \\
\hline \multirow[t]{9}{*}{386} & 77 & Oil & 0.48 & -0.05 & 0.43 \\
\hline & 88 & Oil & 0.52 & -0.22 & 0.30 \\
\hline & 99 & Oil & 0.55 & -0.22 & 0.33 \\
\hline & 110 & Oil & 0.57 & -0.20 & 0.37 \\
\hline & 121 & Oil & 0.59 & -0.23 & 0.37 \\
\hline & 132 & Oil & 0.62 & -0.25 & 0.37 \\
\hline & 33 & Gas & 38.83 & -1.21 & 37.62 \\
\hline & 44 & Gas & 40.64 & -1.25 & 39.39 \\
\hline & 55 & Gas & 42.67 & -1.29 & 41.38 \\
\hline
\end{tabular}

Positive values indicate upward forces and negative values indicate downward forces; $\rho_{\mathrm{HC}}=$ density of hydrocarbons; $\rho_{\mathrm{W}}=$ density of water; $g=$ gravity; $\Delta \Psi=$ fluid overpressure difference between the maximum overpressure (in the lower Vauréal Formation) and that at the base of Macasty; $\Delta z=$ vertical distance between the point of maximum overpressure and the base of Macasty. 
in the northern part of the basin and to the gas window in the southern part. Given the high TOC values and large thickness of the Macasty Formation, large amounts of oil and gas may have been generated. The question is where the hydrocarbons may have flowed and accumulated.

\section{Directions of hydrocarbon migration}

The direction of hydrocarbon migration is determined by three forces including the capillary effect, the buoyancy force, and the impelling force of groundwater flow (Hubbert 1953). Flow patterns are also controlled by the permeability anisotropy of the strata. Thus, under a given hydraulic condition, lateral flow is facilitated by bedding-parallel permeability higher than bedding-perpendicular permeability.

The impelling force of groundwater flow is directly related to the gradient of fluid overpressure. Fluid-flow simulation results indicate that the maximum fluid overpressure near the basin center occurred above the major source rock, forming a pressure barrier unfavorable for upward hydrocarbon migration. In a compaction-only model, maximum overpressure developed in the lower part of the Vauréal shales due to high sedimentation rates during deposition of the Vauréal and Ellis Bay formations. The shales of the Macasty Formation and lower part of the Vauréal Formation compacted rapidly, and the escape of pore fluid was limited by low permeability. Even higher overpressures might have been achieved if we had considered loading from thrusting near the structural front (Ge \& Garven 1992). Sensitivity studies indicate that the magnitude of fluid overpressure depends largely on the permeability of the rocks, although the overpressure distribution pattern remains more or less the same, with maximum overpressures in the lower Vauréal Formation above the Macasty Formation (Fig. 8). Fluid overpressure in the lower Vauréal Formation decreases with time after sedimentation of the Ellis Bay Formation, but this decline is slightly slowed down by the generation of oil and gas. Fluid overpressure then increased during the peak generation of gas (Fig. 5). As a result, a prominent overpressured core was maintained above the Macasty Formation in the central part of the basin during oil and gas generation (Fig. 6). Such a distribution of fluid overpressures is generally favorable for downward migration of hydrocarbons generated in the Macasty Formation in the central part of the basin.

Calculations of the impelling forces of oil and gas considering buoyancy and fluid overpressure indicate that the oil in the Macasty Formation would migrate downward at $428 \mathrm{Ma}$, but that gas and oil generated at $386 \mathrm{Ma}$ would migrate upward (Table 5). Most oil in the central part of the basin would have been generated before $428 \mathrm{Ma}$ (Figs 5A and 9A), so that downward migration of oil is expected near the basin center. Downward migration of oil is also likely in the area further to the north between 428 and $386 \mathrm{Ma}$ if the effect of capillary force is considered. The capillary force tends to expel oil from fine- to coarsegrained sediments (Hubbert 1953). As the Macasty Formation is capped by the fine-grained lower Vauréal Formation and underlain by the coarser-grained Mingan Formation, the general effect of capillary force is to enhance downward migration of oil. For gas, the buoyancy force is so much higher than the downward impelling force related to fluid overpressures (Table 5) that downward migration is unlikely even if the effect of capillary force is considered.

Because the overpressure gradient decreases significantly downward from the Macasty-Mingan contact (Figs 3 and 6 ), it is difficult for oil to migrate all the way to the Romaine Formation. One potential mechanism for oil to reach the Romaine Formation is through episodic opening of subvertical faults as a consequence of fluid overpressure development (Payne et al. 2000). Subvertical faults in the Romaine, Mingan, and Macasty formations, visible on seismic profiles (Lynch \& Trollope 2001; Lynch \& Grist 2002), may have been re-activated by fluid overpressures in the lower Vauréal formation and acted as conduits for downward hydrocarbon flow.

The inferred hydrocarbon flow pattern, combined with the observation that the carbonate rocks of underlying the source beds have locally high porosity (Chi \& Lavoie 2001; Lavoie et al. 2005, 2009), suggests that the Romaine and Mingan formations may have served as reservoirs or carrier beds. Migration of oil in the Romaine Formation is supported by bitumen-coating pore space, hydrocarbon fluid inclusions in late pore-filling calcite and barite cements, and oil and gas shows in almost all ancient drill holes (Chi \& Lavoie 2001; Lynch \& Trollope 2001; Lynch \& Grist 2002; Lavoie et al. 2005, 2009).

Once hydrocarbons were expelled into the underlying carbonates and the downward impelling forces diminished, they could migrate laterally (up-dip) toward the basin margin until migration was stopped by an impermeable barrier. If oil was generated and expelled into the Mingan and Romaine carbonates but did not migrate laterally from the basin center, it would be eventually converted to gas, because the basin center entered the gas window in the later part of the basin history. In the northern part of the basin, fluid overpressures were much smaller than in the central part of the basin, and hydrocarbons were more likely to migrate upward and laterally toward the basin margin.

In summary, the simulation results suggest that oil generated in the organic-matter-rich Macasty shales tended to migrate downward near the basin center and upward in shallow parts of the basin. Natural gas, however, is more likely to migrate upward throughout the basin. The potential hydrocarbon migration pattern is illustrated in Fig. 10. Downward-migrating oil may have been trapped in the carbonates of the Mingan and Romaine formations beneath the source beds, or continued to migrate laterally 
Fig. 10. Flow patterns of hydrocarbon migration in the Anticosti Basin. Oil flows downward near the basin center and then laterally along the carrier beds of the Romaine and Mingan formations (red arrows). Oil generated away from the basin center migrated upward (purple arrows). Potential upward flow of gas is shown by green arrows. The migration paths numbered 1 to 4 are discussed in the text.

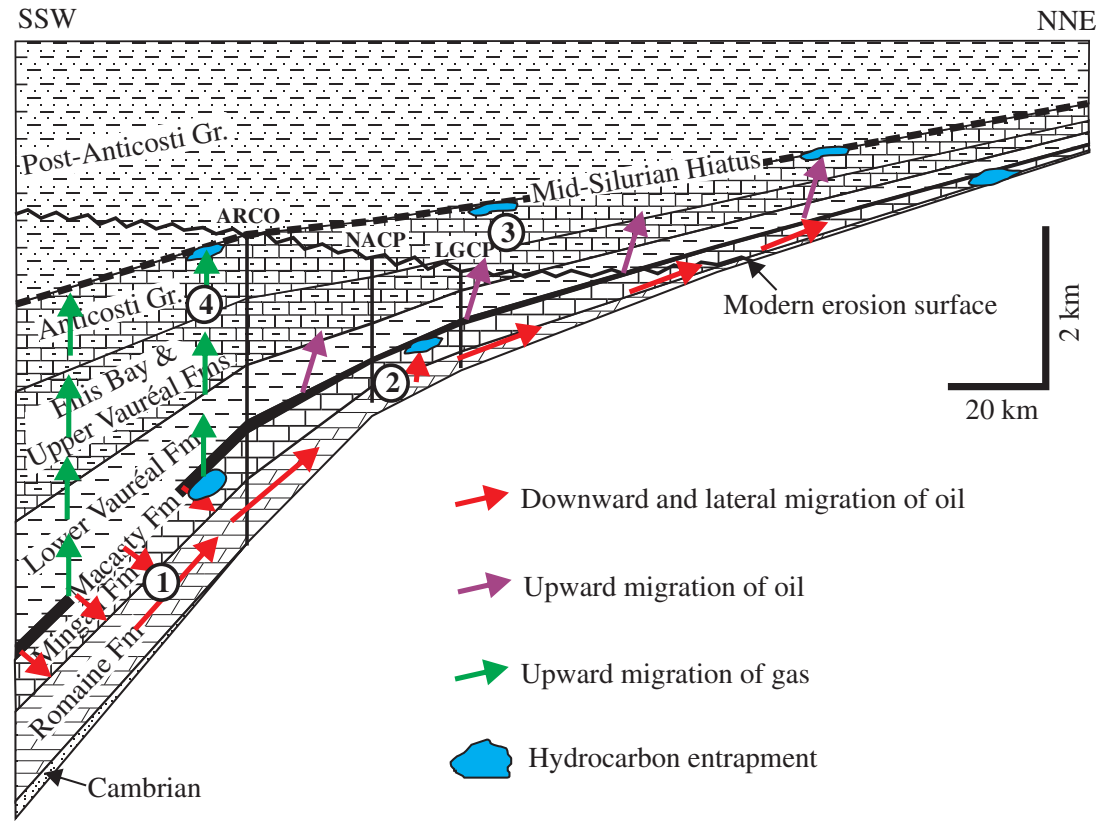

osti Basin, whereas this potential source rock is still in the oil window in the northern part of the basin. Our simulation results indicate that the Macasty Formation in the basin center was in the oil window (10-90\% oil generated) from 440 to $430 \mathrm{Ma}$ (during sedimentation of the Anticosti Group) and the gas window (10-90\% gas generated) from 430 to $405 \mathrm{Ma}$ (Fig. 5A), using the optimal kinetic parameters of Pepper \& Corvi (1995) and Pepper \& Dodd (1995). The age of maturation of the source rock gradually becomes younger toward the basin margin, thus at $386 \mathrm{Ma}$, the end of sedimentation, the Macasty Formation was in the oil window near the middle of the cross-section and immature near the basin edge (Fig. 7). Sensitivity studies indicate that the timing of oil and gas generation is highly uncertain due to uncertainties in kinetic parameters related to kerogen-to-oil and oil-to-gas conversions. Permissible oil-window time intervals for the Macasty Formation at the basin center may vary from 440-430 Ma to 435-415 Ma (Fig. 9A), and the time interval in the gas window may vary from 433-412 Ma to 428-401 Ma (Fig. 9B). The timing of oil and gas windows in other parts of the basin varies accordingly, younging toward the basin margin. Thus, oil generation in the Macasty Formation in the Anticosti Basin as a whole may have lasted from $440 \mathrm{Ma}$ to $<386 \mathrm{Ma}$, and gas generation from $433 \mathrm{Ma}$ to $<386 \mathrm{Ma}$.

The timing of hydrocarbon generation relative to the development of porosity and permeability in potential reservoir rocks or carrier beds is important for hydrocarbon migration and charging. Diagenetic studies indicate that porosity in the Romaine dolostones is mostly secondary in origin, and owes to dissolution by basinal fluids at elevated temperatures (Chi \& Lavoie 2001; Lavoie et al. 2005, 2009). The dissolution event postdated early calcite
Based on organic-matter maturation studies, Bertrand (1987, 1990, 1991) concluded that the Macasty shale reached the gas window in the southern part of the Antic- 
cementation and early dolomitization, was coeval with latestage dolomitization and sulfide mineralization, and predated at least one phase of oil migration (Chi \& Lavoie 2001; Lavoie et al. 2005). Although the age of the porosity-generating dissolution is unknown, it is possible that the dolomitization and dissolution processes took place before or during the generation of oil and gas.

The oil inclusions trapped in late, pore-filling calcite and barite cements in the Romaine Formation at the NACP well on Anticosti Island (Fig. 1B) indicate a relatively late oil migration event at low temperatures and pressures $\left(80^{\circ}-90^{\circ} \mathrm{C}\right.$ and $345-392$ bars; Chi et al. 2000). The oil most likely resulted from secondary migration or dismigration from deeper parts of the basin. One scenario is that oil generated in the Macasty Formation first migrated into the underlying Mingan and Romaine carbonates and then up-dip along the carrier beds. As the Macasty Formation gradually entered the gas window, more gas migrated into the carrier beds, following the same conduits as the oil. The high pressure caused by gas generation may have accelerated oil migration toward the basin margin. Some previously trapped oil may also have been expelled and migrated at a late time, perhaps after maximum burial (386 Ma), due to the late generation of gas.

\section{CONCLUSIONS}

Numerical modeling of fluid flow in the Anticosti Basin indicates that significant fluid overpressures may have developed during basin evolution. Both sediment compaction and hydrocarbon generation contributed to the development of overpressures, but disequilibrium compaction seems to be the most important factor. Maximum fluid overpressures developed in the lower part of the thick Vauréal shale near the basin center, which is located above the Macasty source rocks. This overpressure barrier may have forced oil generated in the Macasty Formation to flow downward into the underlying Mingan and Romaine carbonates, potentially forming hydrocarbon reservoirs. These hydrocarbons could also have migrated further up-dip toward the basin margin through the Mingan and Romaine carbonate carrier beds until they were trapped. In contrast, in the northern part of the basin, fluid overpressures were generally weak, and therefore hydrocarbons (mainly oil) tended to migrate upward. Gas generated in the Macasty Formation is likely to migrate upward throughout the basin. The generation of oil and gas may have lasted after maximum burial, and secondary migration of hydrocarbons may have occurred fairly late in the history of the basin.

\section{ACKNOWLEDGEMENTS}

This study was initially supported by the Earth Science Sector of Natural Resources Canada through the NATional geoscience MAPping (NATMAP) project on the eastern Canada Appalachian forelands and St. Lawrence Platform. Shell Canada, Corridor Resources, and the Ministère des Ressources Naturelles du Québec are thanked for financial support and access to core material at various stages during the project. Additional support came from NSERC (to Chi). Dr M. Nastev of GSC-Quebec and Dr K. Peters of Schlumberger are thanked for reviewing an early draft of the manuscript and for many constructive comments. The study has greatly benefited from comments by two Geofluids reviewers. This study is a Geological Survey of Canada Contribution (20090007).

\section{REFERENCES}

Azmy K, Lavoie D, Knight I, Chi G (2008) Dolomitization of the Aguathuna Formation carbonates of Port au Port Peninsula in western Newfoundland, Canada: implications for a hydrocarbon reservoir. Canadian Journal of Earth Sciences, 45, 795-813.

Bertrand R (1987) Maturation thermique et potentiel pétroligène des séries post-taconiennes du Nord-Est de la Gaspésie et de l'île d'Anticosti. DSc thesis, Neuchâtel, Switzerland, 647 pp.

Bertrand R (1990) Maturation thermique et histoire de l'enfouissement et de la génération des hydrocarbures du bassin de l'archipel de Mingan et de l'île d'Anticosti, Canada. Canadian Journal of Earth Sciences, 27, 731-41.

Bertrand R (1991) Maturation thermique des roches mères dans les bassins des basses-terres du Saint-Laurent et dans quelques buttes témoins au sud-est du Bouclier canadien. International Journal of Coal Geology, 19, 359-83.

Bethke CM (1985) A numerical model of compaction-driven groundwater flow and heat transfer and its application to paleohydrology of intracratonic sedimentary basins. Journal of Geophysical Research, 90, 6817-28.

Bethke CM, Reed JD, Oltz DF (1991) Long-range petroleum migration in the Illinois Basin. AAPG Bulletin, 75, 925-45.

Bethke CM, Lee MK, Quinodoz H, Kreiling WN (1993) Basin Modeling with Basin2, a Guide to Using Basin2, B2plot, B2video, and B2view. University of Illinois, Urbana, $225 \mathrm{pp}$.

Bordenave ML (1993) Applied Petroleum Geochemistry. Editions Technip, Paris, 524 pp.

Bredehoeft JD, Wesley JB, Fouch TD (1994) Simulations of the origin of fluid pressure, fracture generation, and the movement of fluids in the Uinta Basin, Utah. AAPG Bulletin, 78, 1729 47

Burden E, Quinn L, Nowlan G, Bailey-Nill L (2002) Palynology and micropaleontology of the Clam Bank Formation (Lower Devonian) of western Newfoundland, Canada. Palynology, 26, $185-215$.

Castonguay S, Wilson RA, Brisebois D, Desrochers A, Malo M (2005) Compilation géologique, Anticosti-Gaspé-Campbellton, Les ponts géologiques de l'est du Canada, Transect 4, Québec - Nouveau-Brunswick. Geological Survey of Canada, Ottawa, Open File $4883,1 / 125000,4$ sheets.

Chi G (2001) BsnMod: A Windows Program for Simulating BasinScale Fluid Flow and Heat Transfer Processes Related to Sediment Compaction and Tectonic Uplifting in Two Dimensions. Geological Survey of Canada, Ottawa, Current Research 2001D-24, 7 pp.

Chi G, Lavoie D (2001) A Diagenetic Study of Dolostones of the Lower Ordovician Romaine Formation. Anticosti Island: 
Geological Survey of Canada, Ottawa, Current Research 2001D17, 13 pp.

Chi G, Savard MM (1998) Basinal fluid flow models related to $\mathrm{Zn}-\mathrm{Pb}$ mineralization in the southern margin of the Maritimes Basin, eastern Canada. Economic Geology, 93, 896-910.

Chi G, Bertrand R, Lavoie D (2000) Regional-scale variation of characteristics of hydrocarbon fluid inclusions and thermal conditions along the Paleozoic Laurentian continental margin in eastern Quebec, Canada. Bulletin of Canadian Petroleum Geology, 48, 193-211.

Cooper M, Weissenberger J, Knight I, Hostad D, Gillespie D, Williams H, Burden E, Porter-Chaudhry J, Ray D, Clark E (2001) Basin evolution in western Newfoundland: new insights from hydrocarbon exploration. AAPG Bulletin, 85, 393-418.

Desrochers A (2004) Controls on Ancient Rocky Shoreline Development: Examples from the Lower Silurian Chicotte Formation, Anticosti Island; Gulf of St. Lawrence. Geological Association of Canada - Mineralogical Association of Canada Joint Annual Meeting, St Catherines 2004, CD-Rom with abstracts, Montreal, $118 \mathrm{pp}$.

Desrochers A, James NP (1988) Early Paleozoic surface and subsurface paleokarst: middle Ordovician Carbonates, Mingan Islands, Quebec. In: Paleokarst (eds James NP, Choquette PW), pp. 183-210. Verlag, New York.

Duan Z, Moller N, Weare JH (1992) An equation of state for the $\mathrm{CH}_{4}-\mathrm{CO}_{2}-\mathrm{H}_{2} \mathrm{O}$ system: I. Pure systems from 0 to $1000^{\circ} \mathrm{C}$ and 0 to 8000 bars. Geochimica et Cosmochimica Acta, 56, 260517.

Garven G (1985) The role of regional fluid flow in the genesis of the Pine Point deposit, Western Canada sedimentary basin. Economic Geology, 80, 307-24.

Garven G (1989) A hydrogeologic model for the formation of the giant oil sands deposits of the Western Canada Sedimentary Basin. American Journal of Science, 289, 105-66.

Ge S, Garven G (1992) Hydromechanical modeling of tectonically driven groundwater flow with application to the Arkoma foreland basin. Journal of Geophysical Research, 97, 9119-44.

Hansom J, Lee MK (2005) Effects of hydrocarbon generation, basal heat flow and sediment compaction on overpressure development: a numerical study. Petroleum Geoscience, 11, 353-60.

Harrison WJ, Summa LL (1991) Paleohydrogeology of the Gulf of Mexico basin. American Journal of Science, 291, 109-76.

Hubbert MK (1940) The theory of groundwater motion. Journal of Geology, 48, 785-944.

Hubbert MK (1953) Entrapment of petroleum under hydrodynamic conditions. AAPG Bulletin, 37, 1954-2026.

Jacobi RD (1981) Peripheral bulge - a causal mechanism of the Lower/Middle Ordovician unconformity along the western margin of the northern Appalachians. Earth and Planetary Science Letters, 56, 245-51.

Kaufman J (1994) Numerical models of fluid flow in carbonate platforms: implications for dolomitization. Journal of Sedimentary Research, 64, 128-39.

Knight I, James NP, Lane TE (1991) The Ordovician St. George Unconformity, northern Appalachians: the relationship of plate convergence at the St. Lawrence Promontory to the Sauk-Tippecanoe sequence boundary. Geological Society of America Bulletin, 103, 1200-25.

Lavoie D (2008) Appalachian Foreland Basin of Canada. In: Sedimentary Basins of the World - USA and Canada (ed. AD Miall), pp. 65-103. Elsevier Science, the Netherlands.

Lavoie D (2009) Porosity - Permeability Values for Selected Paleozoic Field Samples in Québec. Geological Survey of Canada, Open File 6084, 23 pp.
Lavoie D, Chi G, Brennan-Alpert P, Desrochers A, Bertrand R (2005) Hydrothermal dolomitization in the Lower Ordovician Romaine Formation of the Anticosti Basin: significance for hydrocarbon exploration. Bulletin of Canadian Petroleum Geology, 53, 454-71.

Lavoie D, Pinet N, Dietrich J, Hannigan P, Castonguay S, Hamblin AP, Giles P (2009) Petroleum Resource Assessment, Paleozoic Successions of the St. Lawrence Platform and Appalachians of Eastern Canada. Geological Survey of Canada, Ottawa, Open File $6174,275 \mathrm{pp}$.

Lavoie D, Desrochers A, Dix GR, Knight I, Salad-Hersi O (in press) The Great American Carbonate Bank (GACB) in eastern Canada - an overview. In: The Great American Carbonate Bank: The Geology and Petroleum Potential of the Cambrian - Ordovician Sauk Sequence of Laurentia (eds Wilson JL, Derby J), AAPG Memoir. (in press).

Lee MK, Williams DD (2000) Paleohydrogeology of the Delaware Basin, western Texas: overpressure development, hydrocarbon migration, and ore genesis. AAPG Bulletin, 84, 961-74.

Long DGF (2007) Tempestite frequency curves: a key to Late Ordovician and Early Silurian subsidence, sea-level change, and orbital forcing in the Anticosti foreland basin, Quebec, Canada. Journal of Canadian Earth Sciences, 44, 413-31.

Luo X, Vasseur G (1996) Geopressuring mechanism of organic matter cracking: numerical modeling. AAPG Bulletin, 80, 85674.

Lynch G, Grist AM (2002) Thermal Modeling of the Laurentian Margin Beneath Anticosti Island Using AFTA, ID Well Profiles and Bulk Fluid Inclusions. Canadian Society of Petroleum Geologists, Diamond Jubilee Convention, Calgary 2002, Program with abstracts, Calgary, $210 \mathrm{pp}$.

Lynch G, Trollope SW (2001) Dolomitization, Platform Collapse, and Reservoir Development in Ordovician Carbonates of Anticosti Island, Gulf of St. Lawrence. Canadian Society of Petroleum Geologists, Annual Meeting, Calgary, "Rock the Foundation" Calgary 2001, Program with Abstracts, pp. 126-1-126-6.

Malo M (2004) Paleogeography of the Matapédia basin in the Gaspé Appalachians: initiation of the Gaspé Belt successor basin. Canadian Journal of Earth Sciences, 41, 533-70.

McPherson BJOL, Bredehoeft JD (2001) Overpressures in the Uinta basin, Utah: analysis using a three-dimensional basin evolution model. Water Resources Research, 37, 857-71.

Payne DF, Tuncay K, Park A, Comer JB, Ortoleva P (2000) A reaction-transport-mechanical approach to modeling the interrelationships among gas generation, overpressuring, and fracturing: implications for the Upper Cretaceous natural gas reservoirs of the Piceance Basin, Colorado. AAPG Bulletin, 84, 545-65.

Pepper AS, Corvi PJ (1995) Simple kinetic models of petroleum formation. Part I: oil and gas generation from kerogen. Marine and Petroleum Geology, 12, 291-319.

Pepper AS, Dodd TA (1995) Simple kinetic models of petroleum formation. Part II: oil-gas cracking. Marine and Petroleum Geology, 12, 321-40.

Peters KE, Walters CC, Mankiewicz PJ (2006) Evaluation of kinetic uncertainties in numerical models of petroleum generation. AAPG Bulletin, 90, 387-403.

Quinlan GM, Beaumont C (1984) Appalachian thrusting, lithospheric flexure, and the Paleozoic stratigraphy of the Eastern Interior of North America. Canadian Journal of Earth Sciences, 21, 973-96.

Quinn L, Bashforth AR, Burden ET, Gillepsie H, Springer RK, Williams SH (2004) The Red Island Road Formation: early Devonian terrestrial fill in the Anticosti Foreland Basin, western 
Newfoundland. Canadian Journal of Earth Sciences, 41, 587602.

Roksandic MM, Granger B (1981) Structural styles of Anticosti Island, Gaspé Passage, and eastern Gaspé Peninsula inferred from reflection seismic data. In: Subcommission of Silurian Stratigraphy, Ordovician-Silurian Boundary Working Group: Field Meeting, Anticosti-Gaspé, 1981, Vol. II: Stratigraphy and Paleontology (ed. Lespérance PJ), pp. 211-21. Université de Montréal, Montreal.

Sanford BV (1993) St. Lawrence platform - economic geology. In: Chapter 12, Sedimentary Cover of the Craton in Canada (eds Stott DF, Aitken JD), Geological Survey of Canada, Geology of Canada, No. 5, 787-98.

Sanford BV, Grant AC (1990) Bedrock Geological Mapping and Basin Studies in the Gulf of St. Lawrence. Geological Survey of Canada, Current Research, Paper 90-1B, 33-42.

Sloss LL (1963) Sequences in the cratonic interior of North America. Geological Society of America Bulletin, 74, 93114.

SOQUIP (Société Québécoise d'Initiatives Pétrolières) (1987) Estuary and Gulf of St. Lawrence; Geological, Geophysical and
Geochemical Data Integration. Geological Survey of Canada, Ottawa, Open File 1721.

Speight JG (2006) The Chemistry and Technology of Petroleum, 4th edn. Taylor \& Francis Group, CRC Press, Boca Raton, FL, USA, $984 \mathrm{pp}$.

Swarbrick RE, Osborne MJ, Yardley GS (2002) Comparison of overpressure magnitude resulting from the main generating mechanisms. In: Pressure Regimes in Sedimentary Basins and Their Prediction (eds Huffman AR, Bowers GL), AAPG Memoir, 76, 1-12.

Waldron JWF, Anderson SD, Cawood PA, Goodwin LB, Hall J, Jamieson RA, Palmer SE, Stockmal GS, Williams PE (1998) Evolution of the Appalachian Laurentian margin: lithoprobe results in western Newfoundland. Canadian Journal of Earth Sciences, 35, 1271-87.

Williams EP (1974) Geology and petroleum possibilities in and around Gulf of St. Lawrence. AAPG Bulletin, 58, 1137-55.

Williams H (1995) Temporal and spatial divisions. In: Chapter 2, Geology of the Appalachian-Caledonian Orogen in Canada and Greenland (ed. Williams H). Geological Survey of Canada, Geology of Canada, No. 6, 21-44. 